\title{
Los Fermentos del organismo
}

\author{
Por el Profesor Dr. Mendelssohn-Berlin
}

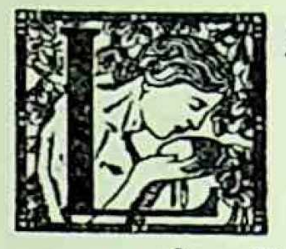

A maravillosa armonía de los diversos fenómenos de la vida fué atribuida hasta fines del siglo XIX a una misteriosa fuerza vital. Hoy, después del sorprendente desarrollo de la nueva química coloidal, se la atribuye a los elementos fundamentales de los seres vivos, a los llamados fermentos. Estos elementos excitan, aun en pequeñas cantidades, las substancias de los cuerpos. Sabios como el profesor Ostwald de Leipzig. el profesor Bredig de Leipzig y otros, pudieron producir este mismo efecto por medio de pequeñas cantidades de combinaciones metálicas y probaron que, agregados en pequeñas dosis, pueden apresurar los procesos químicos en la llamada subdivición coloidal.

La acción principal de los fermentos en el organismo consiste en el desarrollo y la disolución de sus substancias y de los alimentos ingeridos. Producen en los últimos, es decir, en materias extrañas, como por ejemplo las grasas animales y vejetales y la albúmina, una descomposición, y las incorporan a las substancias especificas del cuerpo.

A toda extrema subdivisión de la materia se la llama su estado coloidal, que es de calidad tan fina, que no se pueden observar en el microscopio las partículas componentes; pero puede, en ciertos casos, adquirir la estructura de las grandes moléculas, es decir, de aquellas particulas elementales de que se ha ocupado hasta ahora. como es sabido. la llamada química clásica.

Seria posible llegar a ver esos coloides con el ultra microscopio de Zigmondi Jena, construido por Zeiss. Cierto es que no aparecen luminosas sobre un fondo obscuro; pero se mueven incesantemente en zig-zag. El prolesor Bechhold de Frankfort consiguió por medio de su ultrafiltro, separar las particulas coloides de las verdaderas moléculas.

Los fermentos pueden asimilar, en forma de coloides, otras substancias de un valor extraordinario. Las substancias tintóreas son absorbidas, por ejemplo. por las substancias textiles, coloides estas últimas. Los carbones vegetales y animales, tambiēn coloides, pueden retener substancias tintóreas, aromáticas y saporosas, venenos coloidales y organismos peligrosos, como, por ejemplo, bacterias. Como es sabido. las aguas impuras se hacen potables por medio de filtros de carbón.

Algunos investigadores como Abderhald en Halle, Willstaetter de Munich y Neuberg de Berlin, consiguieron variar de tal modo el electo de los fermentos. que pudo obtenerse del azúcar, por medio de la fermentación, glicerina y grasa. en vez de alcohol. Además, se pudo atenuar o potenciar el efecto de los fermentos añadiendo los llamados colermentos. 
No es de prever la importancia sorprendente y revolucionaria que la doctrina moderna de los fermentos llegará a alcanzar para la medicina y la técnica. Ya es posible secundar a los glóbulos sanguineos en su lucha contra las bacterias infecciosas por medio de cofermentos; se pueden hacer inofensivos por medio de substancias coloidales otras venenosas o perjudiciales para los intestinos y restablecer. sobre una base coloidal, pertubaciones de la digestión.

En cuanto a la técnica, habrá de fundarse en una base científica la práctica. hasta ahora netamente empírica, de las industrias basadas en la fermentación, como, por ejemplo, la industria textil, de curtidos, la tintorería, la fabricación de jabones y bujias, la industria farmacéutica, la producción de substancias alimenticias, la allareria, etc.; en todas las cuales desempeñan los fermentos un papel extraordinario. Con la substitución del método empírico por el científico puede esperarse que el siglo $\mathrm{XX}$ nos haga ver un insospechado progreso en el reino biológico. 